\title{
Analysis Of Agricultural Cultivation As An Attraction For Rural Agrotourism
}

\author{
Arum Pratiwi ${ }^{1}$, Nurul Aini ${ }^{2}$, Karuniawan Puji Wicaksono ${ }^{2}$ \\ ${ }^{I}$ Postgraduate student of Brawijaya University, Malang \\ ${ }^{2}$ Lecturer staff of Brawijaya University, Malang
}

\begin{abstract}
In general, every region in Indonesia seek to develop their optimum potential, one of which is tourism. One of the most potential tourism resources is based on natural resources, including rural and agricultural landscape. One of areas developing the tourism sector is Tanjungan village, in the district of Kemlagi, Mojokerto. Its main object is Tanjungan reservoirs, but there still many obstacles in the development of this area such as lack of travelers attraction to come although there are many other potentials which have not been developed and promoted well. In addition, there still lack of comprehensive understanding about some tourist attraction that can be productively developed. One of these are activities of agricultural and agriculture result cultivation as one of potential for the development of tourist attraction.

The method used 1) Observation and identification; 2) Interview, 3) surveys on tourists and public interest and perception 4) Spatial Analysis; 5) SWOT Analysis. Results of the potential areas analysis show that crops have an area of $84.95 \mathrm{ha}$, for the vegetables area around $9.05 \mathrm{ha}$. While for the fruit area has $28.56 \mathrm{ha}$. According to the tourist's perception and interest about the type of plants that can be used as a tourist attraction, junior high school students prefer to fruit and vegetable crops, for high school and college students prefer to fruits and crops. Based on the SWOT analysis, the strategy used is growth strategy. The setting of planting and harvesting seasons is basis for determining attraction and appeal of agrotourism, and Tanjungan village is plotted as a core zone of the attraction because it has the most dominant potential of agro-tourism attraction and readiness of society.
\end{abstract}

Keywords: Agro Tourism, Agriculture, Fascination

\section{Introduction}

Tourism resource which is potential for being developed is tourism based on natural resources, including rural and agricultural landscapes. The given development is vital that most of Indonesian rural region is still dominated by agriculture activities. The condition has attractive and touristic value which is very potential to be managed and developed (Rustadi, Ernan and Emil, 2007).

Tanjungan village, district of Kemlagi, Mojokerto is one of area that is developing tourism sector and its main object is Tanjungan reservoir. There are obstacles in the development of this region. First, the tourists were not interested to visit because there is no special attraction in the tourist area. Secondly, the lack of tourists comprehensive understanding about attraction that can be developed productively, such as agricultural cultivation activities and the processing of agricultural results as a potential of the tourism attraction development.

To develop the agro area in Tanjungan village, actually it doesn't need to open a new land, which of course requires a very large funding. With local farmland capital or coordinating local farmers to incorporate the existing agricultural lands in the region, agro tourism could be opened to develop. Agricultural activities and daily life of the village community is a pretty interesting mix to watch, learn and enjoy by the tourists (Spillane, 2004). There is a close relationship between the local cultivation of character with the character of the social, economic and cultural village (Lundberg, Stavenga and Krishnamoorthy, 2007). It is recognized from the interplay and complement between them. Character of agricultural cultivation affects the society in farming patterns and utilization of the natural resources, precisely in reviving economic activity and a more dynamic culture will always give effect to the land use patterns at each time (Calina, Lagaru and Croitoru, 2011).

Large farming area, adequate natural environment, farmers living in simplicity and diverse agricultural product are main capital in the development of agro-tourism object in the Tanjungan village. With agro-tourism, natural resources and local culture can be a unique treat and quite attractive for the tourists. All of this stuff is still a raw material that needs to be processed so that it has a tourist attraction value (Malkanthi and Routry, 2011).

The aim of this study, first to identify the biophysical, cultivated crops and cultivation techniques of farming as a potential tourist attraction. Second, to analyzes the tourist's perceptions and desires of cultivation techniques and agricultural commodities as a tourist attraction. Third, to identify the strengths and weaknesses 
of the Tanjungan village object to plan the development of agro-tourism strategy. And fourth, to plan the attraction and agro-tourism in the Tanjungan village landscape.

\section{Site of Research}

\section{Methods}

Research locations were in the Tanjungan village, District of Kemlagi, Mojokerto Regency, East Java. Administratively, Tanjungan village consists of three sub-area namely Tanjungan, Jeruk, and Sukomulyo. Located at an altitude of 37-89 meters above sea level with an area of 259.9 ha. The study began in March 2012 till October 2013.

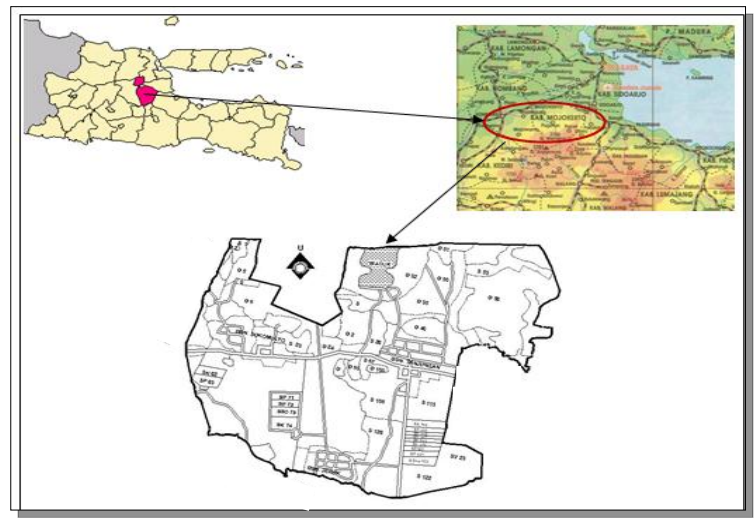

Tanjungan village topography is dominated by flat land (50\%). This indicates that this area is not prone to landslides, $20 \%$ of land area is slightly tilted villages, mostly in form of protected forest areas. The existence of this area is very important, particularly as a water absorption area.

Table 1.Topography of the Tanjungan Village

\begin{tabular}{|l|l|l|l|}
\hline Class & Sloping & $\begin{array}{l}\text { Percentage of } \\
\text { Area }\end{array}$ & Surface Slope \\
\hline A & $0-3$ & $50 \%$ & FLAT \\
\hline B & $3-8$ & $30 \%$ & SLOPING \\
\hline C & $9-15$ & $20 \%$ & $\begin{array}{l}\text { SLIGHTLY } \\
\text { INCLINED }\end{array}$ \\
\hline
\end{tabular}

Source: result of survey, 2013

Demographic data about the state of the population shows the number of Tanjungan villagers in 2012 was listed as 3,092 people. According to Nurisyah (2001), the age of which belong to the productive workforce is aged 15-55 years. Most of Tanjungan Villagers are potential to be labor force for $65.43 \%$. Based on the number of Tanjungan villagers, the total population is 3.092, while in terms of education, about $35.41 \%$ of the population was illiterate and did not complete their elementary school and most of the educated population completed their elementary school (38.87\%).

Tanjungan villagers working in agriculture as a farmer is quite a lot compared to other business sectors. It can be concluded that agriculture plays an important role in the livelihood of rural communities of Tanjungan.

Table 2. Villagers Characteristics

\begin{tabular}{|l|c|c|}
\hline \multicolumn{1}{|c|}{ CHARACTERISTIC } & Number (People) & Percentage (\%) \\
\hline Age< 20 year & 954 & $30,85 \%$ \\
Age 20-40 year & 1145 & $37,03 \%$ \\
Age> 40 year & 996 & $32,21 \%$ \\
Not Graduated from Elementary School & 920 & $30,65 \%$ \\
Graduated from Elementary School & & \\
Graduated from Junior High School & 1202 & $40,04 \%$ \\
Graduated from Senior High School & 566 & $18,85 \%$ \\
& 314 & $10,46 \%$ \\
\hline
\end{tabular}

Source: result of survey, 2013

\section{Spatial Analysis}

The method used was a survey method. The survey of positioning was conducted by using GPS to determine the coordinates of the points that make up a particular network. 
To capture sample plots. Samples were taken from each region observations at 20 points. Location of the observation point is determined by the grid method dividing the map into 12 sections and determine the location of observation point by justify method using observation point located at the point of UTM meeting points distribution or around UTM meeting point. This is held this way in order to spread the observation point evenly in each region so that all regions are represented (Simond, 2003).

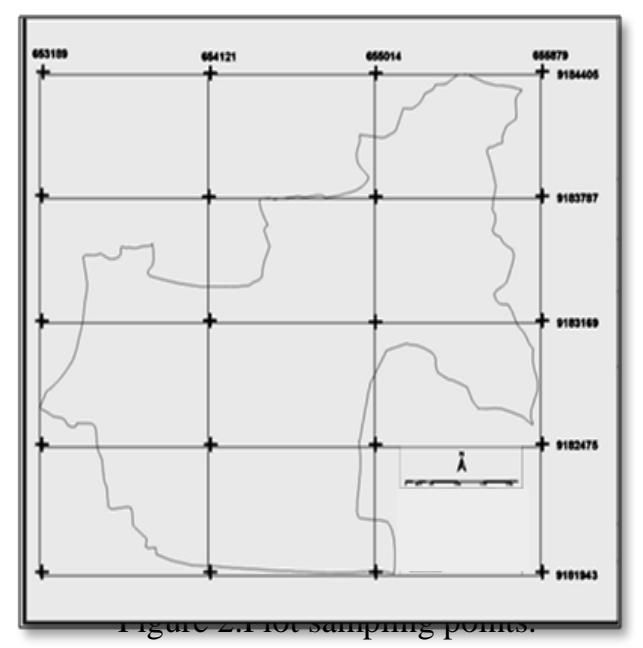

\section{Sampling Metode}

\section{Responden}

Population observed in this study is the number of farmers in Tanjungan Village and potential tourists coming from Surabaya. To determine the sample, this study used random sampling techniques $i$ which each element in the population has an equal chance of being sampled. Sampling methods taken followed the formula developed by Slovin (Umar, 2005), as follows:

$$
\mathrm{n}=\frac{\mathrm{N}}{1+\left(\mathrm{Ne}^{\mathrm{2}}\right)}
$$

Description :

$\mathrm{n}=$ simple size

$\mathrm{N}=$ population size

$\mathrm{e}=$ percent of tolerated inaccuracy due to sampling error.

\section{Object Assessment Method and Tourism Attractions Potential}

Data on plant identification and cultivation attraction as a tourism attraction was processed and calculated using equation (Romanji, 2006):

\section{$\mathrm{S}=\mathrm{N} \times \mathrm{B}$}

Description :

$\mathrm{S}=$ score

$\mathrm{N}=$ total score of elements in each criteria

$\mathrm{B}=$ rate of score

Assessment classification is based on the total number of tourist attraction assessment. Range of assessment classification will be calculated using equation (Oktadiyani, 2006):

Range $=\frac{\mathrm{S} \max -\mathrm{S} \min }{\mathrm{K}}$

Description :

Range : interval value in determining the classification assessment

$S$ max : highest score

$\mathrm{S}$ min : lowest score

$\mathrm{K}$ : total assessment classification

Assessment of plant identification and cultivation as appeal of each component is described in the specific criteria and given a score and should be weighted. Having obtained a total score, the range of classification was made in ranking and the classifications are divided into three classes.

\section{Statistical Analysis}

The main focus of this research is to identify agriculture as a tourist attraction that is linked to tourist's perceptions, therefore correspondence analysis is necessary to determine whether there is a relationship between the two. 


\section{SWOT analysis}

Determination of priority strategies in agro tourism planning by using SWOT analysis approach was based on internal and external factors that affect. From results analysis of observing the two factors, the best combined strategy was obtained for the development of agro-tourism in the area of Tanjungan reservoir.

\section{Planning Concept}

Final result (product) of this research will lead to a concept of agro tourism area planning in Tanjungan Village Mojokerto Regency in general. This process is a realization of synthesis result both in form of area block plan and in form of more detailed description to be further developed and arrangement of agro tourism area.

\section{Results And Discussion}

Identification of Plant Cultivation Type

Crop farming is the main cultivated crops planted in yards and fields for rice food needs and production. Several types of crops cultivated by the local communities (Table 3 ).

Table 3. Type of plants cultivated

\begin{tabular}{|c|c|c|}
\hline No. & Local Name & Scientific Name \\
\hline $\begin{array}{l}1 \\
2 \\
3 \\
4 \\
5 \\
6 \\
7\end{array}$ & $\begin{array}{l}\text { Food Plant } \\
\text { Padi / Paddy } \\
\text { Jagung / Corn } \\
\text { Kedelai / Soy bean } \\
\text { Kacang tanah / Groundnut } \\
\text { Kacang Hijau / Green beans } \\
\text { Ubi kayu / Cassava } \\
\text { Ubi jalar / Sweet potato }\end{array}$ & $\begin{array}{l}\text { Oryza sativa } \\
\text { Zea mays } \\
\text { Glycine max } \\
\text { Arachis hypogea } \\
\text { Phaseolus radiates } \\
\text { Manihotutilissima } \\
\text { Ipomeabatatas }\end{array}$ \\
\hline $\begin{array}{l}1 \\
2 \\
3 \\
4 \\
5 \\
6 \\
7 \\
8 \\
9 \\
10 \\
11\end{array}$ & $\begin{array}{l}\text { Fruit Plant } \\
\text { Mangga / Mango } \\
\text { Sawo / Sapodilla } \\
\text { Sirsat / soursop } \\
\text { Kelengkeng / Longan } \\
\text { Belimbing / Starfruit } \\
\text { Melon / Melon } \\
\text { Pisang / Banana } \\
\text { Srikaya / Sugar apple } \\
\text { Kedondong } \\
\text { Pepaya / Papaya } \\
\text { Nangka / Jackfruit }\end{array}$ & $\begin{array}{l}\text { Mangiferaindica } \\
\text { Manilkarazapota } \\
\text { AnnonaMuricata } \\
\text { Nepheliumlonganum } \\
\text { Averhoacarambola } \\
\text { Cucumismelo } \\
\text { Musa paradisiacal } \\
\text { Annonasavamosa } \\
\text { Spondiasdulcis } \\
\text { Carica papaya } \\
\text { Artocarpusheterophyllus }\end{array}$ \\
\hline $\begin{array}{l}1 \\
2 \\
3 \\
4 \\
5 \\
6 \\
7 \\
8 \\
9\end{array}$ & $\begin{array}{l}\text { Vegetable Plant } \\
\text { Cabai merah / Red chili } \\
\text { Cabai rawit / Cayenne pepper } \\
\text { Terong / Eggplant } \\
\text { Tomat / Tomato } \\
\text { BungaKol / cauliflower } \\
\text { Sawidaging / Mustardmeat } \\
\text { Mentimun / Cucumber } \\
\text { Kacangpanjang /Longbean } \\
\text { Buncis / Snaps }\end{array}$ & $\begin{array}{l}\text { Capcisum annum } \\
\text { Capcisumfrutescens } \\
\text { Solanummelongana } \\
\text { Solanumlycopersicum } \\
\text { Brassica oleraceae } \\
\text { Brassica juncea } \\
\text { Cucumissativus } \\
\text { Vignasinensis } \\
\text { Phaseolus vulgaris }\end{array}$ \\
\hline $\begin{array}{l}1 \\
2 \\
3 \\
4\end{array}$ & $\begin{array}{l}\text { Medicinal Plant } \\
\text { Jahe / Ginger } \\
\text { Kunyit / Turmeric } \\
\text { Kencur } \\
\text { Temulawak / Curcuma }\end{array}$ & $\begin{array}{l}\text { Zingeberofficinale } \\
\text { Curcuma longa } \\
\text { Keemferia galangal } \\
\text { Curcuma xanthorrhiza }\end{array}$ \\
\hline $\begin{array}{l}1 \\
2 \\
3 \\
4 \\
5 \\
6\end{array}$ & $\begin{array}{l}\text { Ornamental Plant } \\
\text { Keladi / Caladium } \\
\text { Lidahmertua } \\
\text { Bunga Sepatu / hibiscus } \\
\text { Kambojajepang / Adenium } \\
\text { Mawar / Rose } \\
\text { Soka }\end{array}$ & $\begin{array}{l}\text { Caladium bicolor } \\
\text { Sansiveratrifaciata } \\
\text { Hibiscus rosasinensis } \\
\text { Adeniumobesum } \\
\text { Rosa damascene } \\
\text { Ixoracoccinea }\end{array}$ \\
\hline
\end{tabular}

Source: Result of survey, 2013

\section{Profile of Tanjungan Rural Agriculture}

The production of fruit and vegetable crops from each village is different in terms of the number and the types. Harvesting period is held every day and the results are transported by the farmers themselves. The harvest products was purchased by individual to be marketed to Surabaya, Jombang and some areas in East Java. 
Table 4. Harvested Area and Agricultural Production

\begin{tabular}{|c|c|c|c|c|}
\hline No. & Harvest & Area & Productivity & $\begin{array}{l}\text { Production Value ( } \\
\text { Rp) }\end{array}$ \\
\hline 1 & $\begin{array}{l}\text { Food Plant } \\
\text { Padi / Paddy } \\
\text { Jagung / Corn } \\
\text { Kedelai / Soy bean } \\
\text { Kacangtanah / groundnut } \\
\text { Kacanghijau / greenbean } \\
\text { Ubikayu / Cassava } \\
\text { Ubijalar / Sweet potato }\end{array}$ & $\begin{array}{r}84.95 \text { ha } \\
54,12 \text { ha } \\
6,2 \text { ha } \\
6,18 \text { ha } \\
9,59 \text { ha } \\
1,22 \text { ha } \\
5,47 \text { ha } \\
2,17 \text { ha }\end{array}$ & $\begin{array}{r}\text { 380,11 quintal/ha } \\
50,50 \text { quintal/ha } \\
32,15 \text { quintal/ha } \\
13.94 \text { quintal/ha } \\
15.23 \text { quintal/ha } \\
8.22 \text { quintal/ha } \\
142.59 \text { quintal/ha } \\
117.43 \text { quintal/ha }\end{array}$ & $\begin{array}{r}1.672 .982 .500 \\
1.393 .860 .600 \\
45.845 .900 \\
30.173 .500 \\
109.687 .500 \\
8.232 .800 \\
54.601 .400 \\
30.580 .800\end{array}$ \\
\hline 2 & $\begin{array}{l}\text { Fruit Plant } \\
\text { Mangga / Mango } \\
\text { Sawo / Sapodilla } \\
\text { Sirsat / Soursup } \\
\text { Kelengkeng / Longan } \\
\text { Belimbing / Starfruit } \\
\text { Pisang / Banana } \\
\text { Srikaya / Sugar apple } \\
\text { Kedondong } \\
\text { Pepaya / Papaya } \\
\text { Nangka / Jackfruit } \\
\text { Melon / Melon }\end{array}$ & $\begin{array}{r}191 \text { tree } \\
23 \text { tree } \\
33 \text { tree } \\
73 \text { tree } \\
52 \text { tree } \\
3276 \text { tree } \\
41 \text { tree } \\
255 \text { tree } \\
94 \text { tree } \\
47 \text { tree } \\
2300 \mathrm{~m}^{2}\end{array}$ & $\begin{array}{r}93.04 \mathrm{~kg} \text { /tree } \\
11.6 \mathrm{~kg} \text { /tree } \\
32.31 \mathrm{~kg} \text { /tree } \\
76.67 \mathrm{~kg} \text { /tree } \\
84.35 \mathrm{~kg} \text { /tree } \\
43.95 \mathrm{~kg} \text { /tree } \\
56.1 \mathrm{~kg} \text { /tree } \\
56.93 \mathrm{~kg} \text { /tree } \\
46.5 \mathrm{~kg} \text { /tree } \\
94.22 \mathrm{~kg} / \text { tree } \\
0.19 \mathrm{~kg} / \mathrm{m}^{2}\end{array}$ & $\begin{array}{r}1.048 .960 .825 \\
115.509 .160 \\
1.600 .800 \\
9.062 .955 \\
58.767 .555 \\
15.351 .700 \\
791.891 .100 \\
25.991 .130 \\
7.258 .575 \\
10.927 .500 \\
11.070 .850 \\
1.529 .500\end{array}$ \\
\hline 3 & $\begin{array}{l}\text { Vegetable Plant } \\
\text { Cabai Besar / Big Chili } \\
\text { Cabai Kecil / Small chili } \\
\text { Terong / Eggplant } \\
\text { Tomat / Tomato } \\
\text { Kol / cabbage } \\
\text { Mentimun / Cucumber } \\
\text { Sawi / Mustard } \\
\text { KacangPanjang / Longbean } \\
\text { Buncis / Snaps }\end{array}$ & $\begin{array}{r}35800 \mathrm{~m}^{2} \\
7000 \mathrm{~m}^{2} \\
4600 \mathrm{~m}^{2} \\
7700 \mathrm{~m}^{2} \\
3600 \mathrm{~m}^{2} \\
200 \mathrm{~m}^{2} \\
4800 \mathrm{~m}^{2} \\
2300 \mathrm{~m}^{2} \\
3700 \mathrm{~m}^{2} \\
1100 \mathrm{~m}^{2}\end{array}$ & $\begin{array}{r}5.2136 \mathrm{~kg} / \mathrm{m}^{2} \\
0.4368 \mathrm{~kg} / \mathrm{m}^{2} \\
0.3738 \mathrm{~kg} / \mathrm{m}^{2} \\
0.593 \mathrm{~kg} / \mathrm{m}^{2} \\
0.7127 \mathrm{~kg} / \mathrm{m}^{2} \\
1.4 \mathrm{~kg} / \mathrm{m}^{2} \\
0.8081 \mathrm{~kg} / \mathrm{m}^{2} \\
0.0113 \mathrm{~kg} / \mathrm{m}^{2} \\
0.4259 \mathrm{~kg} / \mathrm{m}^{2} \\
0.452 \mathrm{~kg} / \mathrm{m}^{2}\end{array}$ & $\begin{array}{r}139.606 .910 \\
66.437 .280 \\
36.968 .820 \\
10.502 .030 \\
14.111 .460 \\
448.000 \\
5.818 .320 \\
38.985 \\
3.939 .575 \\
1.342 .440\end{array}$ \\
\hline 4 & $\begin{array}{l}\text { Medicinal Plant } \\
\text { Jahe / Ginger } \\
\text { Kencur } \\
\text { Kunyit / Turmeric } \\
\text { Temulawak / Curcuma }\end{array}$ & $\begin{array}{r}1982.22 \mathrm{~m}^{2} \\
496.72 \mathrm{~m}^{2} \\
475.9 \mathrm{~m}^{2} \\
679.31 \mathrm{~m}^{2} \\
330.26 \mathrm{~m}^{2} \\
\end{array}$ & $\begin{array}{l}6.29 \mathrm{~kg} / \mathrm{m}^{2} \\
1.81 \mathrm{~kg} / \mathrm{m}^{2} \\
1.18 \mathrm{~kg} / \mathrm{m}^{2} \\
2.25 \mathrm{~kg} / \mathrm{m}^{2} \\
1.05 \mathrm{~kg} / \mathrm{m}^{2}\end{array}$ & $\begin{array}{r}20.329 .150 \\
7.642 .037 \\
4.492 .496 \\
6.113 .790 \\
1.080 .827 \\
\end{array}$ \\
\hline 5 & $\begin{array}{l}\text { Fishery } \\
\text { Kolam / Pond } \\
\text { Jaring Terapung / Floating Net } \\
\text { Karamba / Cages }\end{array}$ & $\begin{array}{r}14 \\
4\end{array}$ & $\begin{array}{l}0,54 \\
0,77 \\
0,23\end{array}$ & $\begin{array}{r}409.752 .000 \\
167.976 .000 \\
\\
24.732 .000\end{array}$ \\
\hline
\end{tabular}

Source: Result of Survey, 2013

Medicinal and ornamental plants are not for sale but for private collection and satisfaction only. While fishery is developed by creating a group of fishery farmers and the result is sold for district area.

\section{Social Character of Community Culture and Tourists Perception \\ Community Preparedness}

According to questionnaire distributed to 90 respondents in three hamlets, the results shows that the Tanjungan hamlet is classified as very good. While the Jeruk hamlet is classified in category of good, and Sukomulyo hamlet is classified as moderate.

Table 5. Results of Community Participation and Preparedness

\begin{tabular}{|l|l|l|l|l|}
\hline No. & Element & Tanjungan & Jeruk & Sukomulyo \\
\hline 1 & An understanding of Agrotourism & 30 & 30 & 30 \\
2 & Public Perception & 25 & 25 & 25 \\
3 & Public Participation & 30 & 30 & 20 \\
4 & The influence of Agrotourism & 30 & 30 & 15 \\
5 & Community Readiness for tourist visits & 30 & 30 & 30 \\
6 & Community Readiness to become a tour guide & 30 & 175 & 15 \\
& Value & 1050 & 1020 & 810 \\
& Score & & \\
\hline
\end{tabular}

Source: Result of Survey, 2013

Form of community participation in the implementation of tourism development, starting from the management of tourism activities involving them in the planning stage, by holding a dialogue with society figures to give input in the development of tourism in Tanjungan. 


\section{Tourist's perception}

In the development of agro tourism we also have to understand what are desired by the travelers or tourists, they are very important stakeholder for being one of the main factors to direct the agro tourism development planning.

Table 6. Tourists Perception and understanding

\begin{tabular}{|c|c|c|c|c|}
\hline No. & Element & $\begin{array}{l}\text { Junior High } \\
\text { School }\end{array}$ & $\begin{array}{l}\text { Senior High } \\
\text { School }\end{array}$ & $\begin{array}{l}\text { College and } \\
\text { Workers }\end{array}$ \\
\hline 1 & \multirow{4}{*}{$\begin{array}{l}\text { Knowing a tourism based on Agriculture (Agrotourism) Frequently } \\
\text { visits to object of agrotourism } \\
\text { Loving the field of agriculture cultivation } \\
\text { Want to try the activity of agricultural cultivation }\end{array}$} & 20 & 25 & 25 \\
\hline 2 & & 15 & 20 & 20 \\
\hline 3 & & 25 & 25 & 25 \\
\hline \multirow[t]{3}{*}{4} & & 25 & 25 & 25 \\
\hline & Value & 85 & 95 & 95 \\
\hline & Score & 510 & 570 & 570 \\
\hline
\end{tabular}

Source: Result of Survey, 2013

Based on questionnaires distributed to 91 respondents in three levels of education the results show that high school students were classified with very interested in agrotourism, while for junior and college students were classified as interested in agro tourism.

Of the total questionnaires distributed, approximately $74.4 \%$ knew about agrotourism. Whereas those who like agriculture was approximately $63.3 \%$ and approximately $60.2 \%$ wanted to try cultivation activities.

\section{Relationship between Types of Cultivated Plant with the Region}

Table 7. Potential between types of commodities to the region

\begin{tabular}{|c|c|c|c|c|c|}
\hline & \multicolumn{5}{|c|}{ Type of Commodity } \\
\hline Region & Food Plant & Fruit Plant & Vegetable plant & Ornamental Plant & $\begin{array}{l}\text { Medicinal } \\
\text { Plant }\end{array}$ \\
\hline Dusun Tanjungan & 145 & 128 & 105 & 95 & 65 \\
\hline Dusun Jeruk & 145 & 128 & 110 & 65 & 50 \\
\hline Dusun Sukomulyo & 140 & 96 & 135 & 70 & 55 \\
\hline
\end{tabular}

Source: Result of Survey, 2013

In Table 7 is clear that the potential in Tanjungan village are food crops, fruits, and vegetables, which appears in the table that Tanjungan Hamlet is potential in food and fruit crops, as well as the hamlet of Jeruk. Slightly different from the Sukomulyo hamlet which is more potential in crops and vegetables. And the three hamlets have in common similarties which has no potential in ornamental and medicinal plants.

The results of Correspondence on Figure 3, describes the closeness occurs between certain plants and demonstrate the potential of each hamlet for certain crops. The figure also shows that the plant was centralized at the center of the village adjacent to the third, it indicates that the crop is potential in the three regions. Meanwhile, the fruits plant are between Jeruk and Tanjungan hamlets, whereas vegetable crops tend to be closer to the Sukomulyo hamlet.
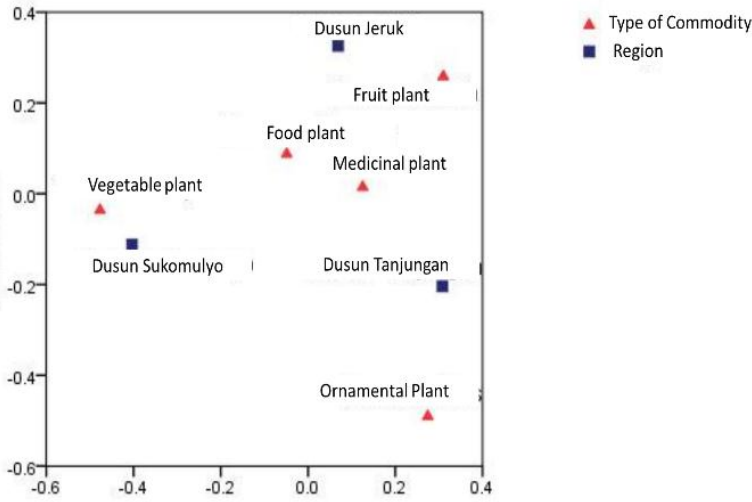

Figure 3. Cartesius Diagram of Correspondence on type of commodity and region

\section{Relationship between the cultivated plants and the tourists}

Based on Table 8, it is clear that the most desirable type of plants according to level of education, most of junior and college students chose the fruit crop while high school students are dominated by those choosing food crops. The type of plant which is the least selected by junior high school students is ornamental plants. Medicinal plants is the least selected by high school and college students. 
Table 8. Potential between the Type of Commodity and Potential Tourists

\begin{tabular}{|l|l|l|l|l|l|}
\hline & \multicolumn{5}{|c|}{ Type of Commodity } \\
\hline Education Level & Food Plant & Fruit Plant & $\begin{array}{l}\text { Vegetable } \\
\text { plant }\end{array}$ & $\begin{array}{l}\text { Ornamental } \\
\text { Plant }\end{array}$ & Medicinal Plant \\
\hline Junior High School & 145 & 128 & 105 & 95 & 65 \\
\hline Senior High School & 145 & 128 & 110 & 65 & 50 \\
\hline College/Workers & 140 & 96 & 135 & 70 & 55 \\
\hline
\end{tabular}

Source: Result of Survey, 2013

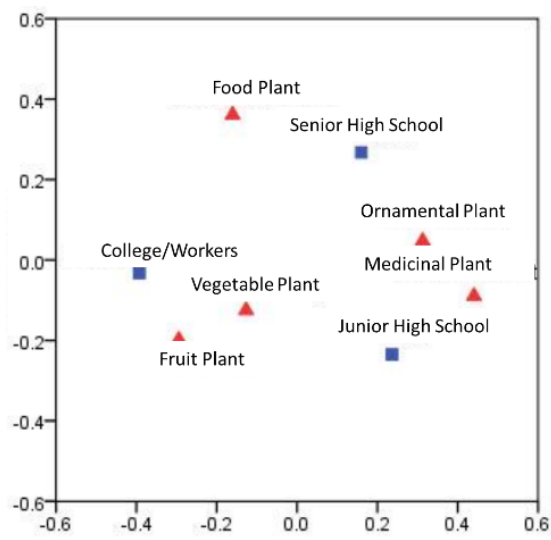

$\Delta$ Type of Commodity

- Potential Tourists

Figure 4. Cartesius Diagram of Correspondence Analysis on the type of commodity and tourists

Figure 4 shows that the characteristics of tourist based on their education level toward types of plants, for junior high school students generally choose the fruit and vegetable plants. As for high school students generally choose food crops, vegetables and ornamental plants. While the college students prefer to fruits, vegetables and food crops.

\section{Mapping results}

The extent of the area based on the results of the mapping. Food crops have the potential extent of 84.95 ha or approximately $38.52 \%$. As for vegetable crops have the potential extent of $11.44 \%$ or about 9.5 ha. While for the fruits have the potential area of 28.56 ha or approximately $20.75 \%$.

The extent of the area in terms of traveler's desire based on their education level. For junior high school students have the potential area of 58.06 ha or $22.34 \%$, the high school students have the potential area of 81.66 ha or approximately $31.42 \%$. And college student's potential covers an area of 81.66 ha or approximately $31.42 \%$.

\section{SWOT analysis}

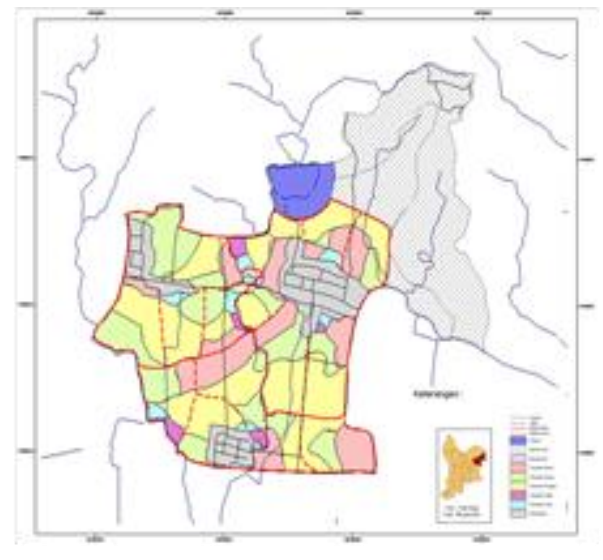

Based on the results of IFAS and EFAS conducted to the development of agrotourism in the Tanjungan village, it can be described in Cartesian diagrams and SWOT strategy formulas. Of each diagram the position for further development is identified, to determine the appropriate strategy.

Development of agro-tourism in the Tanjungan village to be seen as a whole is located at coordinates $(0.9,0.95)$ in quadrant I. This means that the strengths and opportunities outweigh the weaknesses and threats, in which opportunities are greater than its strength. The strategy used is growth strategy, so that appropriate strategies can be formulated to take advantage of strengths and opportunities available. 


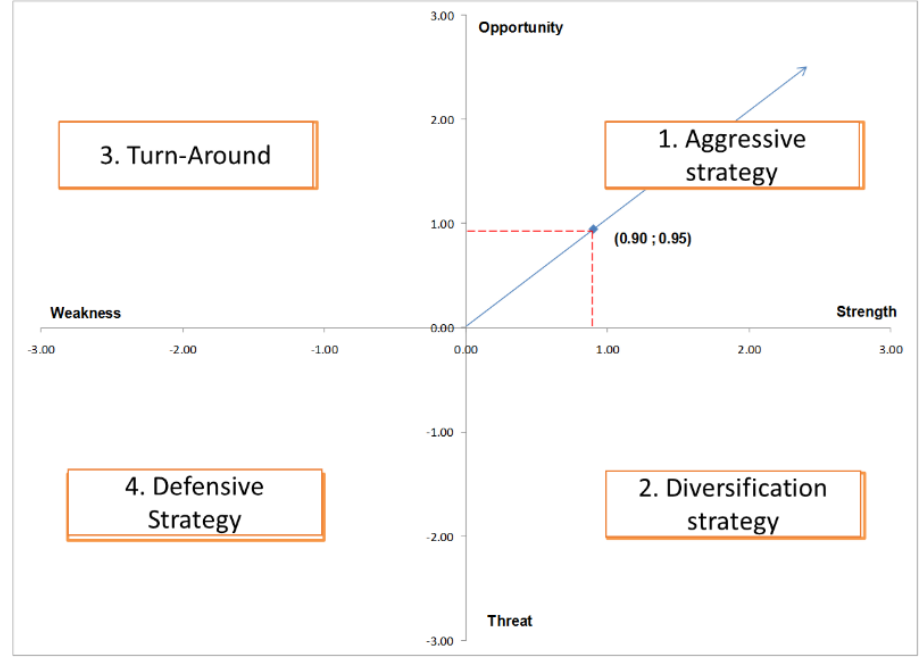

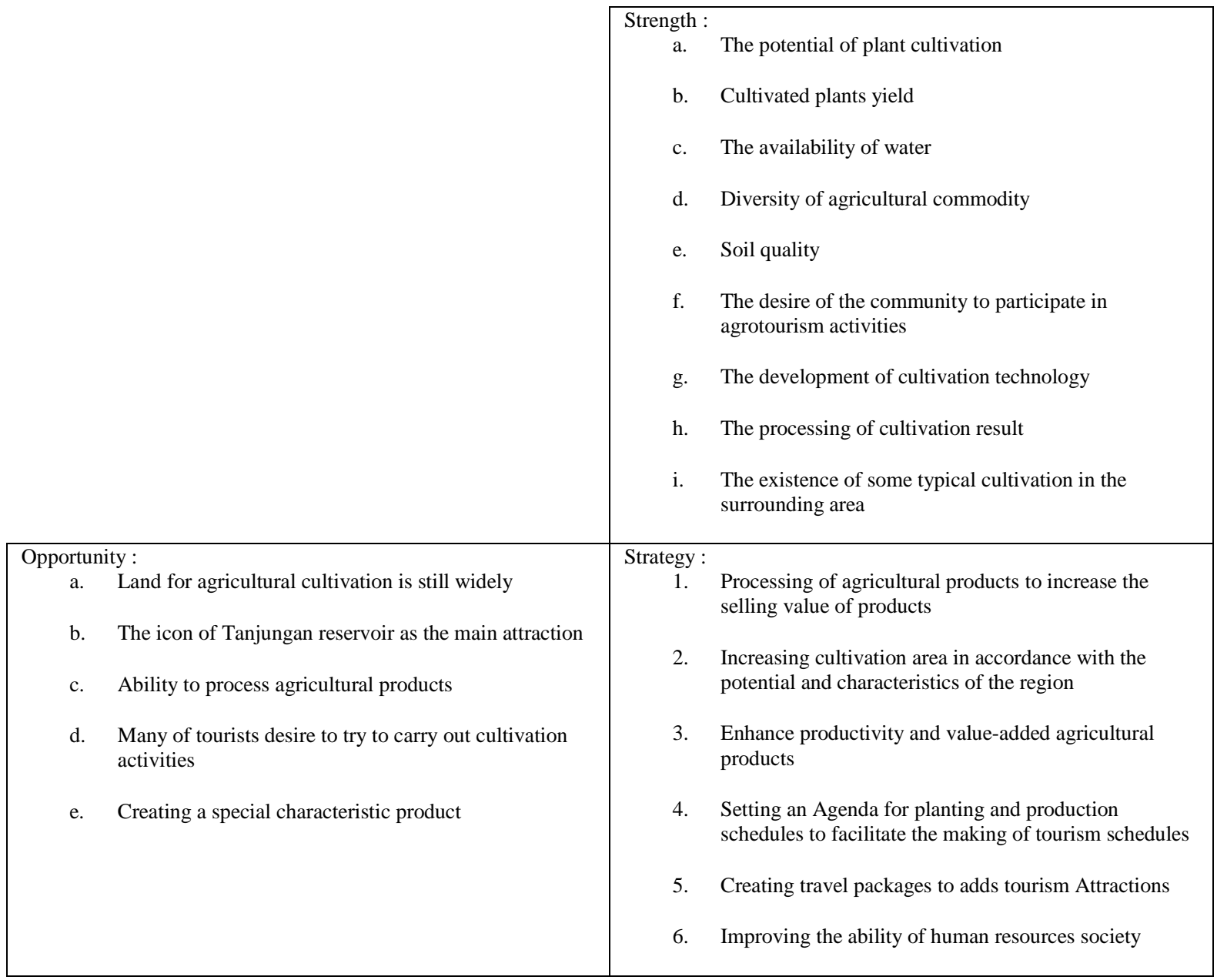

Figure 7. Strategy Formula

\section{Strategy of Planting and Harvest Timing}

To determine the potential of agricultural cultivation appeal to be attractions of tourism, first we have to know the setting of planting and harvesting periods in the village, it is a major factor in determining attraction taken.

Tourism potential observations suggests that rice planting in this region are not in unison, but it creates a beautiful and unique panorama. Tourists can see the complete process of rice cultivation any time, from land preparation to harvest and process of rice mills. So whenever tourists come all the rice cultivation can be enjoyed at one time. 
In contrast to rice crops, the fruits, and vegetable cropping season was based on land and weather conditions so we cannot enjoy all the activities of cultivation at one, but through a special scheduling. Planting and harvesting season calendar can be seen in appendix 1 and 2.

In dry summer months, precisely in August to October is the peak of harvest season of various fruits and vegetables (mango, crushed rock, star fruit, sugar apple, jackfruit, pepper, tomato, and eggplant). While in the months of May, June, July harvest only happens to some fruits and vegetables (only 2-3 commodities).

While breeding period for fishery commodities are deliberately arranged so there is no vacuum attraction in certain months. This can be a sign, in what month the tourist can plan sightseeing activities in accordance with their wishes.

\section{Agrotourism Planning Strategy}

\section{Strategy of Fascination Determination}

Most of products from Agrotourism is culinary or food. Therefore in addition to plan the agricultural activities, Tanjungan village also plan the processing of agricultural products in order to get a higher sale value. Further, the Tanjungan village has positive points due to activity of harvesting in each month from commodities of fishery, food, fruits and vegetables, making it is quite easy to compile a list of menus of different food each month. In order to be an additional characteristic of this tourist village, to manage this menu the tourists allowed to take their own material in the garden and asked the manager to cook it according to the menu offered or they can cook it their self after harvesting ingredients from the garden. The cooking equipment has been already provided by the tour manager.

\section{The determination of zones or spaces strategy}

The concept of space is developed based on agricultural potential areas, related to the method of tourist destination development by Gunn (1997). In addition, considering the needs of tourism visits as well as factors that support the overall tourism.

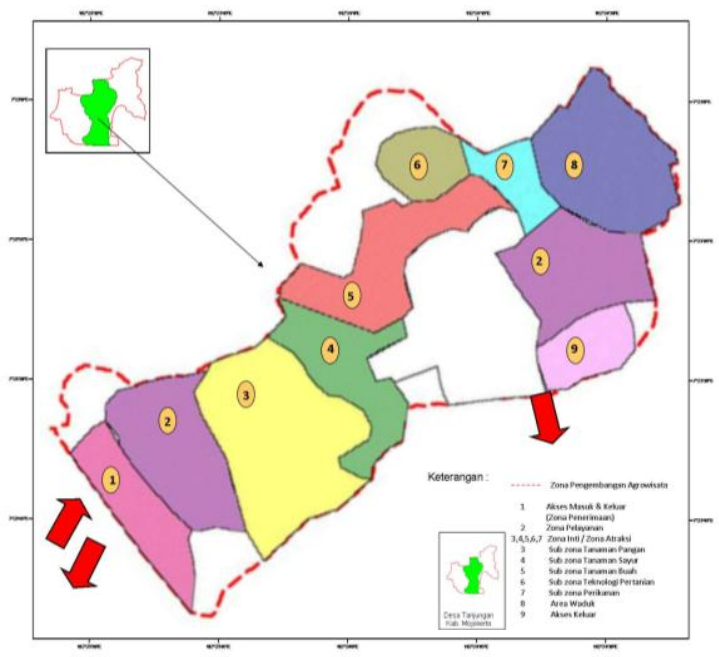

Figure 8. Block Plan of Agrotourism planning

Based on the analysis and comparison of results of the two objects before, the tread will be divided into three main zones, namely agrotourism zone, supporting agrotourism zone and non-agro-tourism zone. Agrotourism zone is a zone that is suitable for agro-tourism activities. These zones tend to be safe based on the analysis of existing slope and proximity to road access. Intensity of use of these zones is often given this area will be visited. This zone covers area of cultivated plants, watershed and public space.

The next is supporting agrotourism zone. This zone has moderate intensity of use. The zone is intended to meet the needs of those in the main zone but still in accordance with the existing environmental conditions. This zone includes a zone of acceptance, room service and public zones.

The last is non agro zone. In this zone, intensity of use is very low. This zone is developed from the addition of conservation zones and buffer zones, which are considered essential to complete the function of the area.

\section{Facilities Planning Strategy}

The existence of adequate tourist facilities will provide an ease and comfort to the tourists. The existing facilities are still limited and spread only on the sub-zone of reservoirs attractions in the area, not spread evenly in the entire part of the region. 


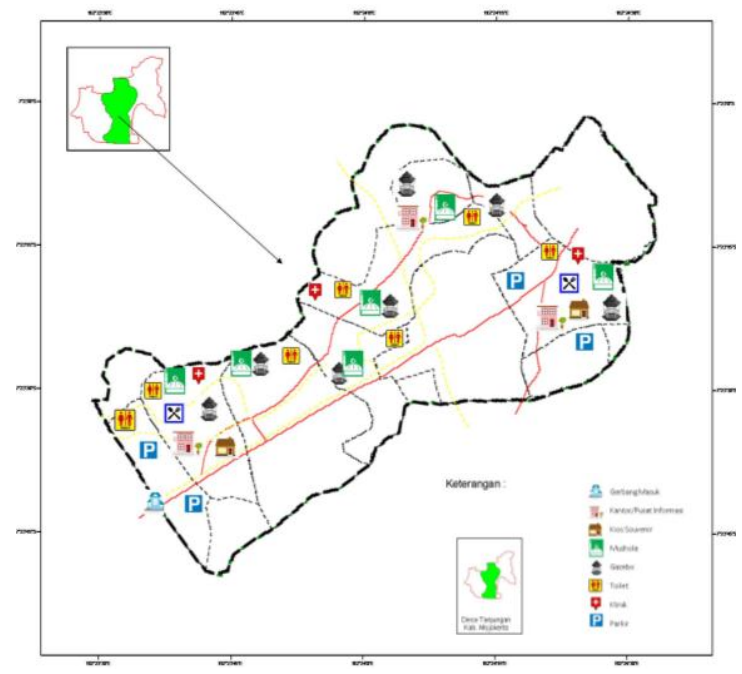

Figure 9. Map of Agrotourism Facilities

Effort to increase the distribution of facilities is urged to do so that the whole region can improve the quality of services to the tourists. I addition, it also needs to be considered in the selection of materials and design of the building. Traditional form patterns and the use of local materials will be able to strengthen the rural feel and character as well as the concept of agrotourism at the site. Further planning process is continued with the development of facilities in connection to the activities developed in each zone.

Facilities are developed to support the activities of active and passive agrotourism. Facilities for active agrotourism activities emphasize entire functions, whereas passive agrotourism activities more emphasize on comfort and aesthetics.

\section{Circulation Path Planning}

Circulation paths should be built with attention to functionality and efficiency so that users can benefit both economically and functionally (Laurie, 1996). To achieve these purpose, the circulation concept used is by functioning the existing roads, accompanied by the addition and improvement of the circulation. So that visitors can enjoy the journey without eliminating the interaction with the surrounding community

In general, distribution of the circulation path is divided into two groups. Consisting of circulation pathways for tourists and circulation for the public.

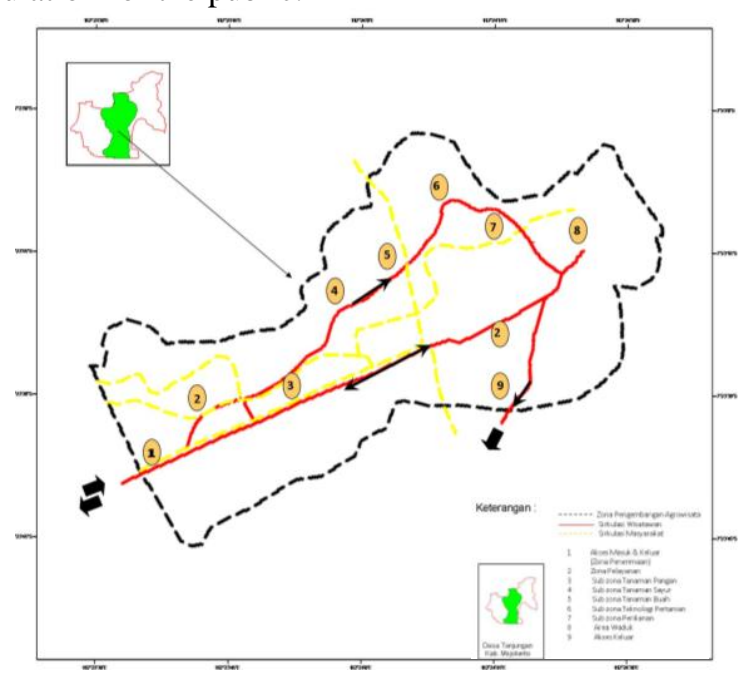

Circulation paths of Tourism

Figure 10. Map of Circulation Planning

It is provided for tourists to enjoy the tourism activities in the region. This pathway connects the subzones in the agrotourism zone. This pathway uses loop pattern (circular) so that the entire object and tourist attractions can be connected to one another.

Circulation paths of community

Is designed to accommodate the movement of people needs. At some points, the path was fused with the tourist track. This is certainly supported by provision of adequate facilities for both purposes. The path of community is mainly used for production activities. 


\section{Planning of Zoning Map}

The zoning map is a complete spatial map of rural development strategies concept in rural agrotourism in Tanjungan Village, Mojokerto regency. The zoning map is a combination of landscape planning strategy containing the arrangement of space, facilities and circulation. For more details of which can be seen in Figure 11 .

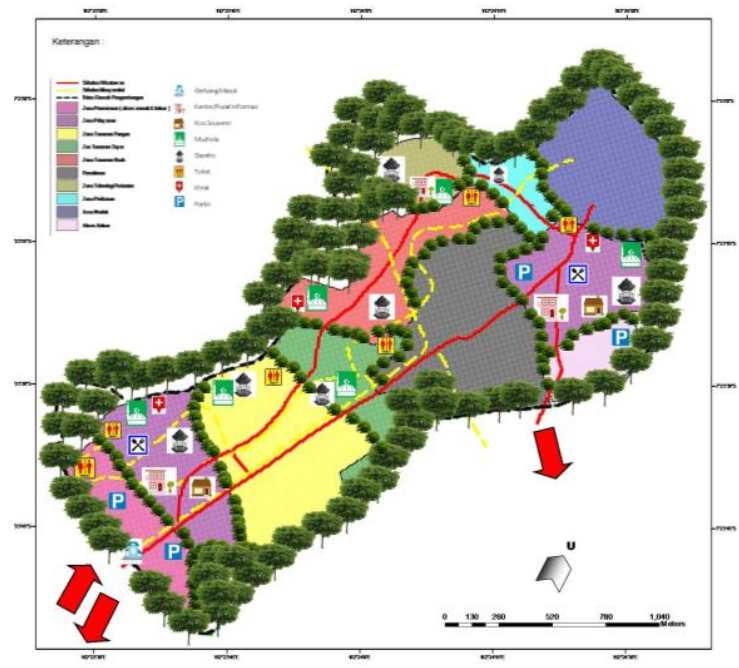

Figure 11. Development strategy map of rural agrotourism in Tanjungan village, Mojokerto regency.

Economic Analysis

Table 9. Income levels of Tanjungan Villagers

\begin{tabular}{|c|c|c|c|c|c|c|c|c|}
\hline \multirow{2}{*}{$\begin{array}{l}\text { Description } \\
\text { rom Agriculture }\end{array}$} & \multicolumn{4}{|c|}{ Before Tanjungan Agrotourism exist } & \multicolumn{4}{|c|}{ After Tanjungan Agrotourism exist } \\
\hline & \multicolumn{2}{|c|}{ Gross Income } & \multicolumn{2}{|c|}{ Net Income } & \multicolumn{2}{|c|}{ Gross Income } & \multicolumn{2}{|c|}{ Net Income } \\
\hline Food Plant & $\mathrm{Rp}$ & $1,840,280,750$ & $\mathrm{Rp}$ & $1,288,196,525$ & $\mathrm{Rp}$ & $1,672,982,500$ & $\mathrm{Rp}$ & $1,087,438,625$ \\
\hline Fruit Plant & $\mathrm{Rp}$ & $1,153,856,908$ & $\mathrm{Rp}$ & $807,699,835$ & $\mathrm{Rp}$ & $1,048,960,825$ & $\mathrm{Rp}$ & $681,824,536$ \\
\hline Vegetable Plant & $\mathrm{Rp}$ & $153,567,601$ & $\mathrm{Rp}$ & $107,497,321$ & $\mathrm{Rp}$ & $139,606,910$ & $\mathrm{Rp}$ & $90,744,492$ \\
\hline Medicinal Plant & $\mathrm{Rp}$ & $22,362,065$ & $\mathrm{Rp}$ & $15,653,446$ & $\mathrm{Rp}$ & $20,329,150$ & $\mathrm{Rp}$ & $13,213,948$ \\
\hline Fishery & $\mathrm{Rp}$ & $662,706,000$ & $\mathrm{Rp}$ & $463,894,200$ & $\mathrm{Rp}$ & $602,460,000$ & $\mathrm{Rp}$ & $391,599,000$ \\
\hline $\begin{array}{l}\text { sales of Compost } \\
\text { Income from Agrotourism } \\
\text { sector }\end{array}$ & $\mathrm{Rp}$ & $3,500,000$ & $\mathrm{Rp}$ & $2,000,000$ & $\mathrm{Rp}$ & $5,000,000$ & $\begin{array}{l}\mathrm{Rp} \\
\mathrm{Rp}\end{array}$ & $\begin{array}{r}3,500,000 \\
1,001,600,000 \\
\end{array}$ \\
\hline Total Income / year & & & $\mathbf{R p}$ & 2,684,941,327 & & & $\mathbf{R p}$ & $3,269,920,600$ \\
\hline Total Income / month & & & $\begin{array}{l}\text { Rp } \\
\text { Rp } \\
717\end{array}$ & $223,745,111$ & & & $\begin{array}{l}\text { Rp } \\
\text { Rp } \\
873\end{array}$ & $272,493,383$ \\
\hline
\end{tabular}

The difference of income before and after the specified status of Tanjungan agrotourism can be seen in Table 5:49. Average income has increased 21.79\% from Rp 717.132 to $\mathrm{Rp} \mathrm{873,376.} \mathrm{Household.} \mathrm{It} \mathrm{is} \mathrm{because}$ some farmers find workers utilize agro byproducts such as parking lots, souvenir sales, consumption, toilet, outbound and others.

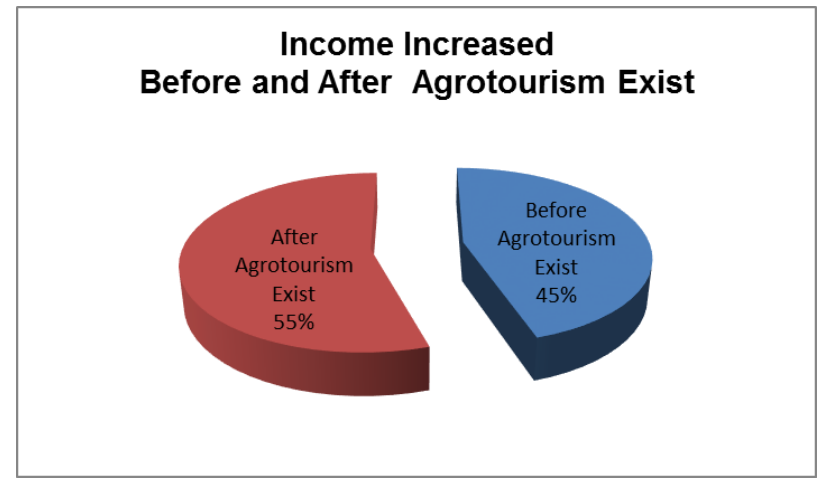

Figure 12. Percentage of Revenue Increase 
An area becomes a site of agrotourism is expected to increase the income of local communities, this will encourage participation of society to preserve the environment and safeguarding of the tourist areas. it will allow tourists to stay longer. If tourists stay longer, this is very beneficial for the local communities and the manager (Smith and Stephen, 2002).

\section{Conclusion}

1. Results of analysis on the potential area and the types of plants to be used as an attraction is type of crops, vegetable and fruits. With a land area for food crops by 84.95 ha or approximately $38.52 \%$ of the entire area of the village, while area of vegetables have $21.44 \%$ of the entire area of the village or about 9.05 ha. As for the fruit crop has an area of 28.56 ha or approximately $20.75 \%$ of the entire area of the region.

2. The result of survey on tourist's interest toward certain type of plants that can be used as an attraction: junior high students choose fruits and vegetable crops, while high school students, college students and workers prefer to food and fruit crops.

3. According to the SWOT analysis, more strengths and opportunities obtained than the weaknesses and threats, in which the opportunities outweigh the strength. The strategy used is growth strategy.

4. Based on the research of the potential for agro-tourism attraction in terms of land use quantity as well as tourist perception, the rice plants in the area of Tanjungan is a major commodity. The potential is because vast areas of rice is the widest area compared to other commodities and spread throughout rural areas of Tanjungan, so that many options to put the rice field to be tourist attraction in the area of Tanjungan. Whereas fruit and vegetable crops is a support for the agrotourism of food crops.

\section{Suggestion}

1. This analysis study is a macro planning step by identifying potential of cultivation space to be used as tourist attractions, therefore more detailed planning can be conducted on the spaces that have been planned in the macro planning.

2. Suggestions for further research is necessary observation of environmental factors and quality of crop plants to increase production as well as to explore the potential for developing rural tourism. In addition it is necessary to guide the villagers in Tanjungan regarding rural tourism in order that communities would participate in the development of rural tourism

\section{Bibliography}

[1]. Calina, A. J. Calina. R. Lagaru and A. Croitoru. 2011. Research on the Potential and Impact of Agrotourism upon the economic and Social- Cultural development of rural areas in the South-West of Romania. Review Article. Agricultural Economics and Rural Sociology. Univ. of Craiova. Romania.

[2]. Gunn, C.A., 1997. Vacationscape: Developing Tourist Area. United States of America.

[3]. Laurie, M. 1996. Pengantar Kepada Arsitektur Pertamanan. Bandung: PT. Intermatra.

[4]. Lundberg, D.E., M.H. Stavenga dan M. Krishnamoorthy. 2007. Ekonomi Pariwisata. PT. Gramedia Pustaka Utama. Jakarta.

[5]. Malkanthi,S.H.P. and J.K. Routry. 2011. Potential for Agritourism Development Evedance from Sri Lanka. The Journal of Agricultural Sciences 6 (1) : 45-58

[6]. Nurisyah, S. 2001. Pengembangan Kawasan Wisata Agro (Agrotourism). Bulletin Taman dan Lanskap Indonesia 2001; 4(2): 2023.

[7]. Oktadiyani, P. 2006. Alternatif Strategi Pengelolaan Taman Wisata Alam Kawah Kamojang Kab. Bandung. Jawa Barat (Skripsi). Fakultas Kehutanan. IPB. Bogor.

[8]. Romanji S. 2006. Penilaian objek dan Daya Tarik Wisata Alam Serta Alternatif Perencanaannya di Taman Nasional Bukit Dua Belas Prov. Jambi .FakultasKehutanan. IPB. Bogor.

[9]. Rustiadi, Ernan, Emil Elestiano. 2007. Agropolitan: Strategi Pengembangan Pusat Pertumbuhan pada Kawasan Perdesaan. Katalog Dalam Terbitan Perpustakaan Nasional RI. Bogor: Ditjen PenataanRuang bekerjasama Crestpen Press.

[10]. Simonds, J.O. 2003. Landscape Architecture. United States of America: McGraw-Hill, Inc.

[11]. Smith and Stephen L. J. 2002. Tourism Analysis: A Handbook. England: Longman Scientific and Technical.

[12]. Spillane, J.J. 2004. Pariwisata Indonesia, Siasat Ekonomi dan Rekayasa Kebudayaan. UGM. Yogyakarta

[13]. Umar, H. 2005. Riset Pemasaran dan Perilaku Konsumen. PT. Gramedia Pustaka Utama Jakarta Business Research Center. Jakarta 
Appendix 1. Planting Periode of various cultivated plants in Tanjungan Village

\begin{tabular}{|c|c|c|c|c|c|c|c|c|c|c|c|c|c|}
\hline \multirow{2}{*}{ №. } & \multirow{2}{*}{ Type of Plant } & \multicolumn{12}{|c|}{ Month in Year } \\
\hline & & jan & feb & March & apr & may & jun & jul & august & sep & okt & nov & $\operatorname{dec}$ \\
\hline 1 & Food Plant & & & & & & & & & & & & \\
\hline $\mathrm{a}$ & Paddy & $83 ; C 2: 01,12: 12 ; 1 ;$ & $: 84 ; 03 ; 02,3 ;: 1 ;: ;$ & $5 ; 85 ; 04 ; 03,4 ; ; 2 ;: F ;$ & $66 ; 86 ; 65 ; 04,5 ; 53 ; ; F$ & $17 ; 87 ; 66 ; 05,6 ; 64 ; ; F$ & $88: 88: C 7 ; 06,7 ;: E 5 ; F$ & $: A 9 ; 89: C 8 ; 07,8 ; 66 ; F 6$ & $10 ; 810 ; 69 ; 08,9 ; 67 ; ; / A A$ & $\mathrm{Al11;} ; 11 ; 010 ; 09,10 ; 88 ; \mathrm{Fu}$ & 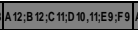 & 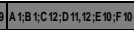 & 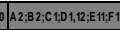 \\
\hline$b$ & Corn & $\overline{D 2}$ & $\mathrm{E2,F2}$ & & $\mathrm{A1}, \mathrm{B1}, \mathrm{C1}$ & D1 & D1 & $D 1$ & $E 1, F 1$ & & $\mathrm{A2}, \mathrm{B2}, \mathrm{CZ} 2$ & $\overline{D 2}$ & $\mathrm{D2}$ \\
\hline $\mathrm{c}$ & Soybean & & & $B 1$ & $\mathrm{A1}, \mathrm{C1}$ & $D 1$ & $D 1, B 2$ & $\mathrm{D1}, \mathrm{A2}, \mathrm{C2}$ & $D 1,2$ & $\mathrm{D2,E1,F1}$ & D2 & $\mathrm{D2}$ & $\mathrm{E2,F2}$ \\
\hline$d$ & Ground nut & $B 2$ & $\mathrm{A2, \textrm {C } 2}$ & $\mathrm{D2}$ & $\mathrm{D} 2$ & D2 & $E 2, F 2$ & $B 1$ & $\mathrm{A1}, \mathrm{C1}$ & D1 & D1 & D1 & $E 1, F 1$ \\
\hline $\mathrm{e}$ & Greenbean & & & $\mathrm{A1}, \mathrm{B1}, \mathrm{C1}, \mathrm{D1}$ & $D 1$ & $\mathrm{D1}, \mathrm{E1}, \mathrm{F1}$ & & & $\mathrm{A2}, \mathrm{B2}, \mathrm{C2}, \mathrm{D2}$ & $\mathrm{D} 2$ & $\mathrm{D2,E2, \textrm {F2 }}$ & & \\
\hline$f$ & Cassava & $\overline{D 2}$ & $\mathrm{D2}, \mathrm{E2}, \mathrm{F2}$ & & & & & $\overline{B 1}$ & $\mathrm{A1}, \mathrm{C1}, \mathrm{D1}$ & D1 & $\mathrm{D1}, \mathrm{E1}, \mathrm{F} 1$ & $\overline{B 2}$ & $\mathrm{A2}, \mathrm{C2}, \mathrm{D2}$ \\
\hline$g$ & sweet potato & $D 1$ & $\mathrm{D} 1, \mathrm{E1}, \mathrm{F1}$ & $\mathrm{A2}, \mathrm{B2}, \mathrm{C2}, \mathrm{D2}$ & $\overline{D 2}$ & $\mathrm{D2}$ & $\overline{D 2}$ & $\mathrm{D2}$ & $\mathrm{D2,E2,F2}$ & $\mathrm{A1}, \mathrm{B} 1, \mathrm{Cl}$ & $D 1$ & $D 1$ & $\overline{D 1}$ \\
\hline 2 & Fruit Plant & & & & & & & & & & & & \\
\hline $\mathrm{a}$ & Mango & & & & & & & & & $D, E, F$ & $\mathrm{D}, \mathrm{E}, \mathrm{F}$ & $D, E, F$ & $\mathrm{D}, \mathrm{E}, \mathrm{F}$ \\
\hline$b$ & Sapodilla & $D, E, F$ & $D, E, F$ & $D, E, F$ & & & & & & & & & $D, E, F$ \\
\hline c & Soursup & & & & & & & & $D, E, F$ & $D, E, F$ & $\mathrm{D}, \mathrm{E}, \mathrm{F}$ & & \\
\hline$d$ & Longan & & $D, E, F$ & $D, E, F$ & $D, E, F$ & & & & & & & & \\
\hline $\mathrm{e}$ & Starrnuit & & & & & & & $D, E, F$ & $D, E, F$ & $D, E, F$ & & & \\
\hline$f$ & Banana & & & $D, E, F$ & $D, E, F$ & $D, E, F$ & $D, E, F$ & $D, E, F$ & & & & & \\
\hline$g$ & Sugar apple & & & & & & & & $\overline{D, E, F}$ & $D, E, F$ & $\overline{D, E, F}$ & & \\
\hline $\mathrm{h}$ & Kedondong & $D, E, F$ & $D, E, F$ & $D, E, F$ & & & & & & & & & \\
\hline$i$ & Papaya & $\mathrm{D}, \mathrm{E}, \mathrm{F}$ & $D, E, F$ & $D, E, F$ & $D, E, F$ & $D, E, F$ & $D, E, F$ & & & & & & $D, E, F$ \\
\hline j & Jackrruit & $D, E, F$ & & & & & & & $D, E, F$ & $D, E, F$ & $D, E, F$ & $D, E, F$ & $D, E, F$ \\
\hline $\mathrm{k}$ & Melon & & $\mathrm{A1}, \mathrm{B1}, \mathrm{C1}$ & $\mathrm{A2,B2, \textrm {CZ } , \mathrm { D1 }}$ & $\overline{D 1,2}$ & $\overline{D 2, E 1, F 1}$ & $\overline{E 2, F 2}$ & & $\mathrm{A3}, \mathrm{B3}, \mathrm{CB}$ & D3 & D3 & $E, F 3$ & \\
\hline 3 & Vegetable Plant & & & & & & & & & & & & \\
\hline$a$ & Big Chilli & & & & $\mathrm{A} 1, \mathrm{B1}, \mathrm{C1}$ & D1 & $\mathrm{D1}, \mathrm{E1}, \mathrm{F1}$ & A2,B2,C2,D1,E1,F1 & $D 1,2 ; E 1, F 1$ & $\mathrm{D2}, \mathrm{E2}, \mathrm{F2}$ & $\mathrm{D2}, \mathrm{E2}, \mathrm{F2}$ & $\mathrm{D2}, \mathrm{E2}, \mathrm{F2}$ & \\
\hline$b$ & Small Chilli & & & & $\mathrm{A1}, \mathrm{B1}, \mathrm{C1}$ & $D 1$ & $\mathrm{D1}, \mathrm{E1}, \mathrm{F1}$ & $\mathrm{A2}, \mathrm{B2}, \mathrm{C2}, \mathrm{D1} 1 \mathrm{E1} 1, \mathrm{F1}$ & $D 1,2 ; E 1, F 1$ & $\mathrm{D2,E2,F2}$ & $\mathrm{D2,E2,F2}$ & $\begin{array}{l}\mathrm{D} 2, \mathrm{E2}, \mathrm{F2} \\
\end{array}$ & \\
\hline $\mathrm{c}$ & Eggplant & & & & & $\mathrm{A1}, \mathrm{B1}, \mathrm{C1}$ & D1 & $\mathrm{D1}, \mathrm{E1}, \mathrm{F1}$ & $\mathrm{A} 2, \mathrm{B2}, \mathrm{C2}, \mathrm{D1}, \mathrm{E1}, \mathrm{F1}$ & $D 1,2 ; E 1, F 1$ & $\mathrm{D2}, \mathrm{E2}, \mathrm{F2}$ & $\mathrm{D2}, \mathrm{E2}, \mathrm{F2} 2$ & $\mathrm{D2}, \mathrm{E2}, \mathrm{F2}$ \\
\hline$d$ & Tomato & & & $\overline{\mathrm{A} 1, \mathrm{B1}, \mathrm{Cl}}$ & $\mathrm{D1,E1,F1}$ & $\mathrm{D1,E1,F1}$ & D1,E1,F1 & & $\mathrm{A} 2, \mathrm{B2}, \mathrm{C2}$ & $\overline{D 2, E 2, F 2}$ & $\mathrm{D2,E2, \textrm {F2 }}$ & $\mathrm{D2,E2,F2}$ & \\
\hline $\mathrm{e}$ & Cabbage & & $\mathrm{A} 1, \mathrm{B1}, \mathrm{C1}$ & D1 & $\mathrm{D1}, \mathrm{E1}, \mathrm{FT}$ & & $\mathrm{A2}, \mathrm{B2}, \mathrm{C2}$ & D2 & $\mathrm{D2}, \mathrm{E2}, \mathrm{F2}$ & & & & \\
\hline$f$ & Cucumber & $\mathrm{A1}, \mathrm{B1}, \mathrm{C1}$ & $D 1$ & $\mathrm{E1,F1}$ & $E 1, F 1$ & & & & & $\mathrm{A1}, \mathrm{B1}, \mathrm{C1}$ & $\overline{D 1}$ & $E 1, F 1$ & $E 1, F 1$ \\
\hline$g$ & Mustard & $\mathrm{D2}, \mathrm{E2}, \mathrm{F2}$ & & $\mathrm{A3}, \mathrm{B3}, \mathrm{CB}$ & $\mathrm{DB}, \mathrm{EB}, \mathrm{F3}$ & & $\mathrm{A4}, \mathrm{BA}, \mathrm{CA}$ & $\mathrm{DA}, \mathrm{E4}, \mathrm{F4}$ & & $\mathrm{A1}, \mathrm{B1}, \mathrm{C1}$ & $\mathrm{D1}, \mathrm{E1}, \mathrm{F1}$ & & $\mathrm{A2}, \mathrm{B2}, \mathrm{C2}$ \\
\hline $\mathrm{h}$ & Longbean & $\mathrm{D1}, \mathrm{E1}, \mathrm{F1}$ & $\mathrm{D1}, \mathrm{E1}, \mathrm{F1}$ & & $\mathrm{A2}, \mathrm{B2}, \mathrm{C2}$ & D2 & $\mathrm{D2}, \mathrm{E2}, \mathrm{F2}$ & $\mathrm{D2}, \mathrm{E2}, \mathrm{F2}$ & & & & $\mathrm{A1}, \mathrm{B1}, \mathrm{C1}$ & D1 \\
\hline$i$ & Snaps & $\mathrm{D1}, \mathrm{E1}, \mathrm{F} 1$ & $\mathrm{D} 1, \mathrm{E} 1 \mathrm{F1}$ & & $\mathrm{A} 2, \mathrm{B2}, \mathrm{C} 2$ & D2 & $\mathrm{D} 2, \mathrm{E2}, \mathrm{F2}$ & $\mathrm{D} 2, \mathrm{E2}, \mathrm{F} 2$ & & & & $\mathrm{~A} 1, \mathrm{~B} 1 \mathrm{C1}$ & D1 \\
\hline
\end{tabular}

Description : A.Seedling; B: Ground/media Cultivation;C:Planting; D:Maintenance; E:Harvesting; F.Postharvesting

$1,2, \ldots \quad$ : Planting Periode

Source $\quad$ : Result of survey, 2013

Appendix 2. Schedule of various plants harvesting seasons in Tanjungan Village

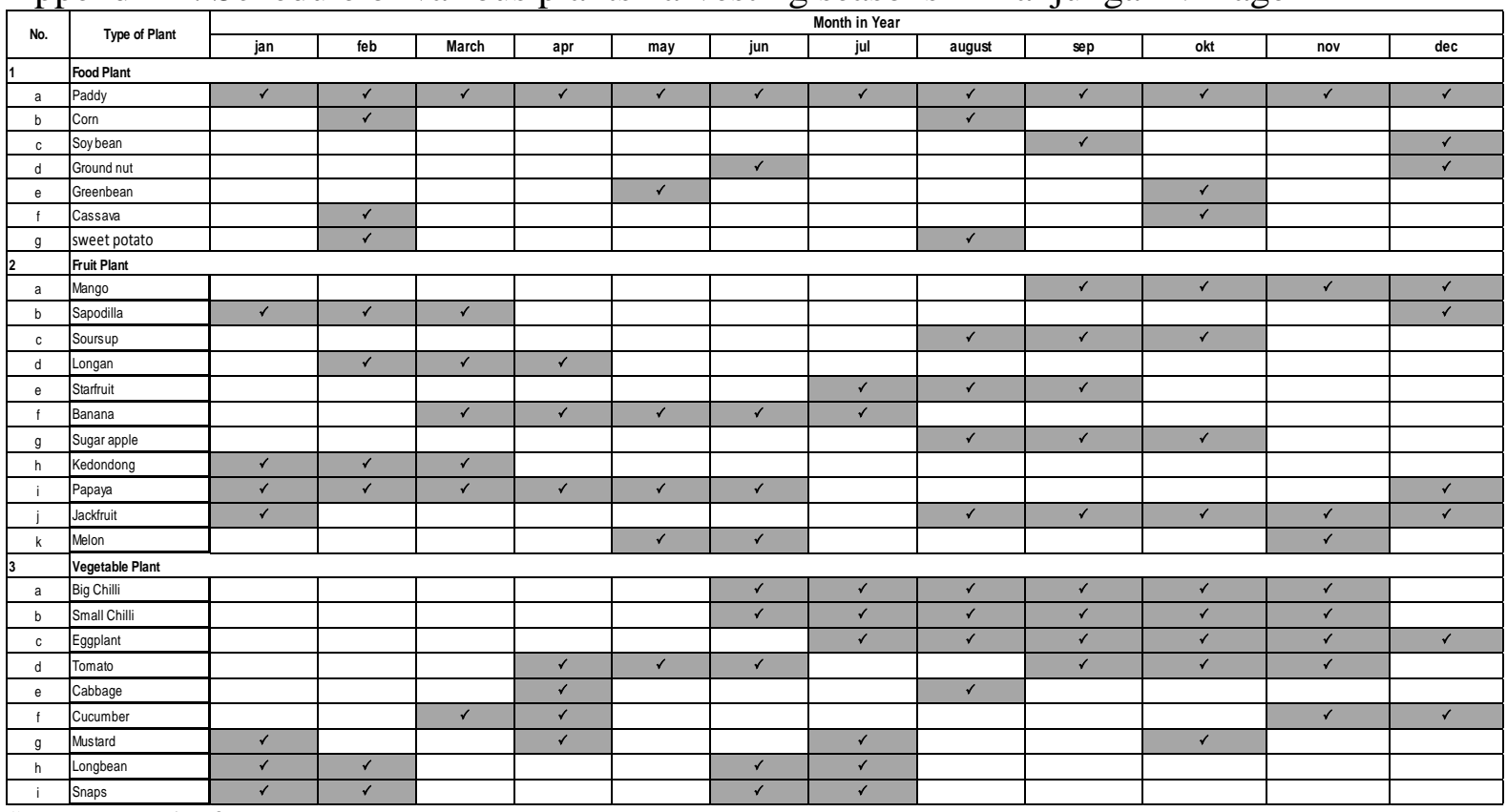

Source : Result of survey

Appendix 3. Periode of fish farming seedling in Tanjungan Village

\begin{tabular}{|c|c|c|c|c|c|c|c|c|c|c|c|c|c|}
\hline \multirow{2}{*}{ No. } & \multirow{2}{*}{ Fish Species } & \multicolumn{12}{|c|}{ Month in Year } \\
\hline & & jan & feb & March & apr & may & jun & jul & august & $\operatorname{sep}$ & okt & nov & dec \\
\hline$a$ & Gurame & $\mathrm{Cl}$ & $\mathrm{CI}$ & $\mathrm{Cl}$ & $\mathrm{Cl}$ & 91,01 & $D 1$ & D1 & A1 & $B 1$ & $\mathrm{B1}, \mathrm{CI}$ & $\mathrm{CI}$ & $\mathrm{Cl}$ \\
\hline$b$ & Nila & $\mathrm{Cl}$ & $c 1,01$ & $D 1$ & $D 1$ & A2 & $B 2$ & $\mathrm{C2}$ & C2,02 & D2 & D2 & $A 1$ & $B 1$ \\
\hline$c$ & Mujari & D2 & $\mathrm{D2}$ & A1 & $B 1$ & $\mathrm{Cl}$ & $C 1,01$ & D1 & D1 & A2 & $\mathrm{B2}$ & $\mathrm{C2}_{2}$ & $C 2,02$ \\
\hline$d$ & Lele & B2,01 & $\mathrm{C2}$ & D2 & $\mathrm{A3}, \mathrm{D2}$ & $B 3,02$ & $\mathrm{CB}$ & D3 & $\mathrm{A1}, \mathrm{DB}$ & $\mathrm{B1}, 03$ & $\mathrm{Cl}$ & $\mathrm{D} 1$ & $\mathrm{A2,01}$ \\
\hline
\end{tabular}

Description : A.Seedling; B:Cultivation ; C:Maintenance; D:Harvesting; 
$1,2, \ldots \quad$ : Planting Periode

Source : Result of survey, 2013

Appendix 4. Periode of Fish Harvesting Season in Tanjungan Village

\begin{tabular}{|c|l|c|c|c|c|c|c|c|c|c|c|c|c|}
\hline \multirow{2}{*}{ No. } & \multirow{2}{*}{ Fish Species } & \multicolumn{10}{|c|}{ Month in Year } \\
\hline & & jan & teb & March & apr & may & jun & jul & august & sep & okt & nov & dec \\
\hline a & Guvame & & & & & $\checkmark$ & $\checkmark$ & $\checkmark$ & & & & & \\
\hline$b$ & Nila & & $\checkmark$ & $\checkmark$ & $\checkmark$ & & & & $\checkmark$ & $\checkmark$ & $\checkmark$ & & \\
\hline$c$ & Mujair & $\checkmark$ & $\checkmark$ & & & & $\checkmark$ & $\checkmark$ & $\checkmark$ & & & & $\checkmark$ \\
\hline$d$ & Lele & $\checkmark$ & & $\checkmark$ & $\checkmark$ & $\checkmark$ & & $\checkmark$ & $\checkmark$ & $\checkmark$ & & $\checkmark$ & $\checkmark$ \\
\hline
\end{tabular}

Source : Result of survey, 2013 